\title{
The Influence of Perceived Ease of Use, Perceived Usefulness and Consumer Satisfaction towards Online Purchasing Behavior
}

\author{
Ahmad Syakir ${ }^{\mathrm{a}}$ dan Adi Irawan Setiyanto ${ }^{\mathrm{b}, *}$ \\ ${ }^{a}$ Manajemen Bisnis, Politeknik Negeri Batam, -, Indonesia \\ bManajemen Bisnis, Politeknik Negeri Batam,adi@polibatam.ac.id, Indonesia
}

\begin{abstract}
This study aims to examine the effect of perceived ease of use, perceived usefulness and consumer satisfaction on online purchasing behavior. This study used 200 respondents taken from the general public living in the area of Batam. The type of data used in this study is the interval scale. Scaling method used in the instrument of Likert scale with 5 rating categories. The results of this study indicate that the variables perceived ease of use, variable perceived usefulness and consumer satisfaction effect on online purchasing behavior either partially or simultaneously. For further research is expected to increase the number of samples, change the sample or add research variables.
\end{abstract}

Keywords: perceived ease of use, perceived usefulness, consumer satisfaction and online purchasing behavior 


\section{Introduction}

Indonesia is the country with the sixth most internet user in the world. The number of internet users in Indonesia each year continues to grow, more than 50 percent or about 143 million people have been connected to the internet network throughout 2017, while in 2016 the number of internet users only $34 \%$ (88.1 million) of the total population. With the growth of internet users, Bank Indonesia estimates there are 24.7 million people who shop online. The value of ecommerce transactions is predicted to reach Rp144 trillion in 2018, up from Rp69.8 trillion in 2016 and Rp25 trillion in 2014. The value of technology investments in e-commerce and financial technology reaches Rp22.6 trillion (eMarketer, 2014) . This gives an idea that digital economic activity has a great opportunity and continues to grow.

E-commerce is an abbreviation of electronic commerce which means a transaction that includes various business activities ranging from purchases to sales made through internet-based network media. The internet serves as a medium that provides efficiency and effectiveness in many ways. This role is necessary to support performance and facilitate the work (Wardhana, 2016). Peceived ease of use is a convenience that consumers perceive in connection with the use of the internet for various purposes to be achieved (Lui and Jamieson, 2003). Perceived ease of use is defined as the extent to which a person believes that the use of a particular system will improve his performance (Saade and Bahli, 2005).

The benefits of e-commerce for companies or organizations are able to reach a vast marketing area without having to spend much on advertising costs. The perception of benefits is a consumer's belief about the extent to which it will get better from online transactions with a particular website. Lui and Jamieson (2003) suggest that perceived usefulness identifies the benefits consumers receive by using the internet to make transactions. Perceived usefulness (PU) is defined as the extent to which a person believes that the use of a particular system will be free of effort (Yea Lin, Fang, and Chung Tu, 2010). This opinion explains that perceived usefulness is a level of confidence that the use of the system will facilitate a variety of jobs so that work can be done more quickly.

Consumer behavior in e-commerce is also influenced by satisfaction in online transactions and is a major indication for consumers to like an online shop, and is the best indication of their desire to return to the site (Johnson, in Saragih \& Ramdhani, 2012).
Consumer satisfaction in conducting online transactions is indicated to affect consumer confidence that will ultimately affect consumer attitudes in making repurchase (Elvandri, 2011). Based on the results of research by Jiang and Rosenbloom (2005), customer satisfaction while shopping online and customer satisfaction after the purchase (Sukma, 2011) became an indicator where an online store site can retain its customers by increasing interest to shop back to the site. According to Saragih and Ramdhani (2012), the factors that affect the customer's intention to return online shopping are customer satisfaction and trust.

This research is the development of previous research conducted by Setya and Liswandi (2016) who studied the "Influence of Consumer Decision-making Styles towards Purchasing Behavior". In contrast to Setya and Liswandi (2016) studies that took samples from people living in the Jakarta area. This research will take samples from people living in Batam area with 19-34 year olds who have online shopping experience at online shop shop site, such as Lazada, Tokopedia, Buka Lapak, Shoppe and OLX Indonesia. People living in the Batam area with a productive age group of 19-34 are considered to be able to present how to feel the ease of use, benefits and satisfaction when shopping online against buying behavior.

Based on the explanation of the background that has been described, the problem formulation in this research is, firstly how partially influence perceived ease of use (PEOU), perceived usefulness (PU) and consumer satisfaction toward online buying behavior. Second, what is the effect of simultaneously perceived ease of use (PEOU), perceived usefulness (PU) and consumer satisfaction on online purchasing behavior.

\section{Literature Review}

Understanding consumer behavior according to Tjiptono (1997) are individual actions directly involved in the business of obtaining, using (consuming) and determining products (goods and services), including decision-making processes that precede and follow those actions.

This theory is proposed by Cox (1967). Cue utilization theory helps to understand how a consumer processes product cues to assess product quality. Through cue utilization theory, the product is described as "the array of cues. These cues serve not only as an indicator of quality for the buyer but also as 
a signal to the consumer that enables consumer decision making".

Consumption theory by Baudrillard (1998) states that modern society is a consumptive society. People who are constantly consuming. But the consumption is no longer just an activity to meet the basic needs and functional human. Society is not enough just to consume "clothing, food, board" just to survive. Although biological fulfillment of food and clothing needs is sufficient, but in social intercourse with other human beings, modern man must consume more than that. It can be said that modern society now lives in consumer culture. As a culture, consumption affects everyday life and structures the daily practice of society.

Theory of reasoned action (TRA) was first coined by Ajzen in 1980 (Jogiyanto, 2007). This theory is structured using the basic assumption that humans behave in a conscious way and consider all available information. In this TRA, Ajzen (1980) which states that a person can do or not to do a behavior depends on the intention possessed by that person. Furthermore, Ajzen (1980) suggests that the intention of performing or not performing certain behaviors is influenced by two basic determinants, the first relating to attitudes and others related to social influences ie subjective norms.

Theory of planned behavior (TPB) is a further development of TRA. Ajzen (1988) adds a construct that does not yet exist in the TRA, ie the control of perceived behavior. This construct is added in an effort to understand the limitations of the individual in order to perform certain behaviors (Chau and $\mathrm{Hu}$, 2002). In other words, whether or not a behavior is undertaken is determined not only by subjective attitudes and norms, but also the individual's perception of the control that he can exert from his belief in that control.

\section{Hypotheses Development}

Davis (1989) found that the perception of ease is a perception of someone who is not bothered with various other activities in making transactions. The perception of ease of online transactions refers to the individual perception of easy online shopping transactions. In conducting transactions, prospective consumers only make a little effort, not too complicated so as to facilitate the prospective consumer to make purchasing decisions through internet products. The convenience perception of such transactions can be simple ordering procedures, varied and easy payment procedures, an informative and enjoyable buying process and fast and precise product delivery process. The indicators that can be used for this variable include faster work, job performance, improve productivity, effectiveness, make the job easier and useful.

According to Davis (1989) in Khalifa and Liu (2007), perceived usefulness is defined as a central idea explaining the usefulness or use of information technology. Perceived usefulness becomes one of the main determinants of consumer intention formation. Consumers will make a buyback when they find an advantage in making an online purchase. When consumers find it easy to interact with e-commerce pages, including searching for information about products and making payments online, they will consider shopping online. The indicators that can be used for these variables include easy to learn, can be controlled, clear and easy to understand, flexible, easy to become skilled and easy to use.

According to Kotler and Keller (2012) satisfaction is defined as the feeling of pleasure or disappointment of a person resulting from comparing the perceived product performance or the outcome of expectations. Consumers will feel dissatisfied if the company's performance is not in accordance with consumer expectations and vice versa. If the company's performance matches or exceeds consumer expectations then consumers will feel satisfied. Schiffman and Kanuk (2010) describe satisfaction as an individual perception of the performance of a product or service in relation to expectations or expectations. According to Lovelock and Wirtz (2011) defines satisfaction as an attitude like assessment after having consuming experience. Consumer satisfaction is an impact that arises from a hope or expectation. If a consumer has a bad experience and not as expected, then consumers will feel disappointed or not satisfied. The indicators that can be used for this variable include satisfaction with the product, purchasing process and service or service.

Based on the thoughts and explanations above, it can be drawn hypothesis as follows:

H1: There is an influence of perceived ease of use toward online purchasing behavior.

$\mathrm{H} 2$ : There is an influence of perceived usefulness toward online purchasing behavior.

H3: There is an influence of consumer satisfaction toward online buying behavior.

$\mathrm{H} 4$ : There is a simultaneous influence of perceived ease of use, perceived usefulness and consumer satisfaction towards online purchasing behavior. 


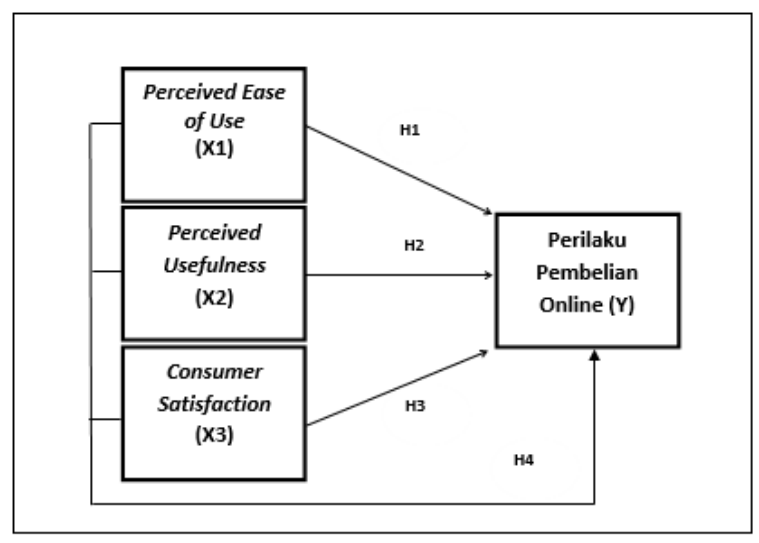

Fig. 1. Research Method

\section{Research Method}

This study uses a quantitative approach. The type of data used is the interval data is the value of classification, order (there is sequence) and distance. Scaling method used is rating scale with Likert scale method. This study uses five points Likert scale, with details 1 (strongly disagree), 2 (disagree), 3 (neutral), 4 (agree), 5 (strongly agree). Sources of data in this study are primary sources. The population in this study is the general population living in Batam City, Indonesia.

The technique of determining the number of samples using Roscoe's method (1975) with the provisions of researchers using samples of more than 30 and less than 500 respondents. In multivariate studies (including multivariate regression analysis) the sample size should be several times larger (10 times) than the number of variables to be analyzed. The larger the number of samples (the closer to the population) the less probability of a generalization error and vice versa, the smaller the number of samples (away from population) the greater the probability of generalization error (Hendry, 2015). In this study used a sample of 200 people. The criteria used in this study are the general population living in Batam area with the productive age group 19-34 years old who have online shopping experience at online shop site, such as Lazada, Tokopedia, Buka Lapak, Shoppe and OLX Indonesia. Analyzer the data used is regression with IBM SPSS Statistics 17.

\section{Discussion}

\section{Characteristics of Respondents}

The questionnaires were distributed as many as 200 and all returned because the researchers went directly to the respective respondents. The researcher attaches 20 statement items to be filled by each respondent. Each respondent who has completed the questionnaire can be identified by sex, age, last education, profession, monthly expenses, most visited websites, and how often to use the website in a month. The goal is that researchers know the general characteristics of the research respondents. From the 200 respondents data obtained, the respondents with female gender are more dominant with the percentage of $55 \%$ when compared with the male respondents who have a percentage of $45 \%$. Majority respondents are aged 19 22 years with percentage of $61 \%$ and have last education that is SMA/equivalent with percentage of $69,5 \%$. The respondent's characteristics based on the current profession show that 104 of 200 respondents $(52 \%)$ are still Student with total monthly expenses of $<\mathrm{Rp} 1,000,000$ (36\%). Characteristics of respondents based on the most frequently visited website shows that 113 of 200 respondents $(56.5 \%)$ use the Shopee site with the frequency of using the website in a month $>5$ times with a percentage of $52 \%$.

\section{Validity Test}

\begin{tabular}{|c|c|c|c|c|}
\hline \multirow{3}{*}{ Variabel } & \multicolumn{3}{|c|}{$\begin{array}{c}\text { Table } 1 \\
\text { Validity Test }\end{array}$} & \\
\hline & & & liditas & \\
\hline & Item & $r$ hitung & r tabel & Kesimpulan \\
\hline \multirow{6}{*}{ Perceived Ease Of Use (x1) } & Item 1 & 0.700 & \multirow{6}{*}{0.1381} & Valid \\
\hline & Item 2 & 0.723 & & Valid \\
\hline & Item 3 & 0.725 & & Valid \\
\hline & Item 4 & 0.785 & & Valid \\
\hline & Item 5 & 0.835 & & Valid \\
\hline & Item 6 & 0.852 & & Valid \\
\hline \multirow{6}{*}{ Perceived Usefulness (X2) } & Item 1 & 0.855 & \multirow{6}{*}{0.1381} & Valid \\
\hline & Item 2 & 0.681 & & Valid \\
\hline & Item 3 & 0.606 & & Valid \\
\hline & Item 4 & 0.779 & & Valid \\
\hline & Item 5 & 0.759 & & Valid \\
\hline & Item 6 & 0.760 & & Valid \\
\hline \multirow{4}{*}{ Consumer Satisfaction (X3) } & Item 1 & 0.766 & \multirow{4}{*}{0.1381} & Valid \\
\hline & Item 2 & 0.708 & & Valid \\
\hline & Item 3 & 0.786 & & Valid \\
\hline & Item 4 & 0.667 & & Valid \\
\hline \multirow{4}{*}{$\begin{array}{l}\text { Perilaku Pembelian Online } \\
\text { (Y) }\end{array}$} & Item 1 & 0.752 & \multirow{4}{*}{0.1381} & Valid \\
\hline & Item 2 & 0.853 & & Valid \\
\hline & Item 3 & 0.870 & & Valid \\
\hline & Item 4 & 0.866 & & Valid \\
\hline
\end{tabular}

Validity test conducted in this research is by doing bivariate correlation between each score indicator with total score of construct. The researchers only tested the validity of 30 respondents from each 
statement. Validity test results for perceived ease of use (PEOU), perceived usefulness (PU), consumer satisfaction and online purchasing behavior can be seen in Table 1.

Based on Table 1, the validity test for perceived ease of use variables, perceived usefulness, consumer satisfaction and online purchasing behavior indicate that each indicator is valid, since each item of statement has $r$ count greater than $r$ table. The value of $\mathrm{r}$ table used is 0.1381 with a significance level of 0.05 using a two-sided test.

\section{Reliability Test}

The reliability test is performed to measure the extent to which the measurements of a test test remain consistent after repetition of the subject and under the same conditions. Research is considered to be reliable when delivering consistent results for similar measurements. A construct or variable is said to be reliable if it gives Cronbach's Alpha value >.60 (Ghozali, 2012). Reliability test results can be seen in Table 2.

Table 2

Reliability Test

\begin{tabular}{|c|c|c|c|c|}
\hline \multirow[b]{2}{*}{ Variabel } & \multicolumn{4}{|c|}{ Reliabilitas } \\
\hline & Nof item & $\begin{array}{l}\text { Cronbach's } \\
\text { Alpha }\end{array}$ & $\begin{array}{l}\text { Cut Off Cronbach's } \\
\text { Alpha }\end{array}$ & Kesimpulan \\
\hline $\begin{array}{l}\text { Perceived Ease Of Use } \\
\text { (x1) }\end{array}$ & 6 & 0.861 & 0.60 & Reliabel \\
\hline $\begin{array}{l}\text { Perceived Usefuiness } \\
\text { (x2) }\end{array}$ & 6 & 0.812 & 0.60 & Reliabel \\
\hline $\begin{array}{l}\text { Consumer Satisfaction } \\
\text { (x3) }\end{array}$ & 3 & 0.709 & 0.60 & Reliabel \\
\hline $\begin{array}{l}\text { Perilaku Pembelian } \\
\text { Online (Y) }\end{array}$ & 3 & 0.854 & 0.60 & Reliabel \\
\hline
\end{tabular}

Table 2 shows all variables have Cronbach's Alpha value greater than 0.60 so it can be concluded that perceived ease of use (PEOU), perceived usefulness (PU), consumer satisfaction and online purchasing behavior are reliable.

Descriptive statistics

Table 3

Descriptive Statistics

\begin{tabular}{lccccc}
\hline \multicolumn{1}{c}{ Variabel } & N & Minimum & Maximum & Mean & $\begin{array}{c}\text { Standar } \\
\text { Deviation }\end{array}$ \\
\hline Perceived Ease Of Use (X1) & 200 & 16 & 30 & 23.87 & 2.379 \\
Perceived Usefulness (X2) & 200 & 15 & 30 & 24.31 & 2.339 \\
Consumer Satisfaction $(\mathbf{X} 3)$ & 200 & 8 & 20 & 15.16 & 1.922 \\
Perilaku Pembelian Online & 200 & 8 & 20 & 15.53 & 2.286 \\
(Y) & & & & & \\
\hline
\end{tabular}

Descriptive statistics are used to provide an overview of a data that can be seen from a mean, minimum, maximum, and standard deviation.
Descriptive statistical results in this study using the program SPSS 17. Descriptive statistical test results table can be seen in Table 3 .

Based on Table 3, it is known that the perceived ease of use (X1) variable with the number of data (samples) of 200 has an average value of 23.87, with a minimum number having perceived ease of use of 16 and a maximum of 30 . while the standard deviation of 2.379. From the above descriptive statistical results it can be concluded that the overall of the total sample responded almost agree on the perceived ease of use variable. Variable perceived usefulness (X2) with the amount of data (sample) taken by the researcher as much as 200 data has an average value of 24.31 , with a minimum number of perceived usefulness value of 15 and the maximum amount of 30 while the standard deviation of 2.339. From the above descriptive statistical results it can be concluded that overall of the total sample responded almost agree on perceived usefulness variables.

Variable consumer satisfaction (X3) with the amount of data (sample) taken by the researcher as much as 200 data has an average value of 15.16 , with a minimum amount having consumer satisfaction value of 8 and the maximum amount of 20 while the standard deviation of 1.922 . From the results of descriptive statistics above can be concluded that the overall of the total sample answered almost agree on the variable consumer satisfaction. The variable of online purchasing behavior (Y) with the amount of data (sample) taken by the researcher as many as 200 data has an average value of 15.53 , with a minimum amount that has the value of online purchasing behavior of 8 and the maximum amount of 20 while the standard deviation of 2.286. From the above descriptive statistical results it can be concluded that the overall of the total sample responded almost agree on the variables of online purchasing behavior.

\section{Normality test}

Normality test aims to test whether the residual value is normally distributed. Normality test in this study using the Kolmogorov-Smirnov One-Sample Test on SPSS 17 using a significance level of 0.05 . Normality test is said to be normal if the significance value is more than 0.05 . Good data is data that is normally distributed ie the data held can represent the total population to be sampled. SPSS Output Results can be seen in Table 4.

Based on Table 4 it can be seen that the value of Kolmogorov-Smirnov is 1,079 and the significance 
value is 0.195 . The value of significance is greater than 0.05 . It can be concluded that the residual data is normally distributed.

\begin{tabular}{|c|c|}
\hline \multicolumn{2}{|c|}{$\begin{array}{c}\text { Table } 4 \\
\text { Normality Test }\end{array}$} \\
\hline Uji Normalitas & Unstandardized Residual \\
\hline Kolmogorov-Smirnov Z & 1.079 \\
\hline Asymp. Sig. (2-tailed) & 0.195 \\
\hline
\end{tabular}

\section{Multicolinearity Test}

The multicollinearity test is used to test whether there are independent variables that can be seen from the tolerance and variance inflation factor (VIF). Multicollinearity occurs when VIF $>10.00$, tolerance $<0.10$ and vice versa if VIF $<10.00$, tolerance $>0.10$ then it can be concluded not to happen multicollinearity. The results of multicollinearity testing can be seen in Table 5 .

Table 5

Multicollinearity Test

\begin{tabular}{ccc}
\hline Variabel Independen & Signifikansi & VIF \\
\hline Perceived Ease Of Use $(\mathrm{X} 1)$ & 0.699 & 1.432 \\
Perceived Usefulness (X2) & 0.727 & 1.375 \\
Consume Sotisfoction (X3) & 0.719 & 1.390 \\
\hline
\end{tabular}

Based on Table 5, it shows that all independent variables have tolerance values $>0.10$ and $\mathrm{VIF}<10.00$ can be concluded that there is no multicollinearity.

\section{Heteroscedasticity Test}

The heteroscedasticity test aims to test whether in the regression model there is a variance inequality of the residual of one observation of another. A good regression model is a homoscedasticity or regression model with no heteroscedasticity. There are several ways to detect the presence or absence of heteroskedastisitas such as park test, glesjer test, see the pattern of regression graph, and test the spearman correlation coefficient. In this research, heteroscedasticity test used is spearman correlation coefficient test. The results of the heteroscedasticity test are shown in Table 6.

Based on Table 6, it shows that all independent variables perceived ease of use (X1), perceived usefulness (X2) and consumer satisfaction (X3) have significance value $>0.05$ can be concluded that there is no heteroscedasticity in this regression model.

Table 6

Heteroscedasticity Test

\begin{tabular}{cc}
\hline Variabel Independen & Signifikansi \\
\hline Perceived Eose Of Use (X1) & 0.131 \\
Perceived Usefulness (X2) & 0.209 \\
Consume Sotisfaction (X3) & 0.073 \\
\hline
\end{tabular}

\section{Partial Significance Test (T Test)}

The first hypothesis proposed in this study is that there is perceived ease of use influence on online purchasing behavior. This hypothesis can be supported if the value of significance obtained shows a value less than 0.05 and is not supported if the significance value obtained is more than 0.05 . Hypothesis testing used in this study is a two-tailed test called a two-way test. The results of the analysis can be seen in Table 7 .

Table 7

First Hypothesis Test Results

\begin{tabular}{lccc}
\hline \multicolumn{1}{c}{ Variabel } & Koefisien & $\mathbf{t}$ & Sig. \\
\hline Constant & 7.634 & 4.961 & .000 \\
Perceived Ease Of Use & .331 & 5.145 & .000 \\
\hline R Square & .118 & & \\
Adjusted R Square & .114 & & \\
\hline
\end{tabular}

Based on Table 7, it can be seen that the results obtained are perceived ease of use having significance of 0.000 smaller than $0.05(0.000<0.05)$. From result of significance hence can be concluded that perceived ease of use have an effect on buying behavior online. This suggests that the first hypothesis (H1) is supported. The equation of a simple linear regression formula can be written as follows: $\mathrm{PPO}=7.634+$ 0.331 PEOU. The equation in this regression shows that there is influence between independent variable to dependent variable.

The meaning of this regression equation is a constant value of 7.634 indicating if perceived ease of use is constant or fixed, then the average rate of online purchasing behavior is 7.634. The regression coefficient perceived ease of use of 0.331 means that if perceived ease of use increases one unit then will be followed by an increase in the level of online purchasing behavior of 0.331 . The coefficient of determination (adjusted R2) of 0.114 means that $11.4 \%$ of online purchasing behavior can be explained by perceived ease of use variables, while the 
remaining $88.6 \%$ is explained by other variables outside the model.

The second hypothesis proposed in this study is that there is perceived usefulnes influence on online purchasing behavior. This hypothesis can be supported if the value of significance obtained shows a value less than 0.05 and is not supported if the significance value obtained is more than 0.05 . Hypothesis testing used in this study is a two-tailed test called a two-way test. The results of the analysis can be seen in Table 8 .

Table 8

Second Hypothesis Test Results

\begin{tabular}{lccc}
\hline \multicolumn{1}{c}{ Variabel } & Koefisien & T & Sig. \\
\hline Constant & 11.193 & 6.712 & .000 \\
Perceived Usefulness & .178 & 2.609 & .010 \\
\hline R Square & .033 & & \\
Adjusted R Square & .028 & & \\
\hline
\end{tabular}

Based on Table 8, it can be seen that the results obtained are perceived usefulness having significance of 0.010 is smaller than $0.05(0.010<0.05)$. From the results of significance it can be concluded that perceived usefulness effect on buying behavior online. This suggests that the second hypothesis (H2) is supported. The equation of a simple linear regression formula can be written as follows: PPO $=11.193+$ $0.178 \mathrm{PU}$. The equation in this regression shows that there is influence between independent variable to dependent variable.

The meaning of this regression equation is a constant value of 11.193 indicating if perceived usefulness is constant or fixed, then the average rate of online purchasing behavior is 11.193. The regression coefficient perceived usefulness of 0.178 means that if perceived usefulness increases one unit then will be followed by an increase in the level of online purchasing behavior of 0.178 . Coefficient of determination (Adjusted R2) of 0.028 this means that $2.8 \%$ of online purchasing behavior can be explained by perceived usefulness variables, while the remaining $97.2 \%$ is explained by other variables outside the model.

The third hypothesis proposed in this study is that there is influence consumer satisfaction on online purchasing behavior. This hypothesis can be supported if the value of significance obtained shows a value less than 0.05 and is not supported if the significance value obtained is more than 0.05 . Hypothesis testing used in this study is a two-tailed test called a two-way test. The results of the analysis can be seen in Table 9.
Table 9

Results of the Third Hypothesis Test

\begin{tabular}{lccc}
\hline \multicolumn{1}{c}{ Variabel } & Koefisien & $\mathrm{t}$ & Sig. \\
\hline Constant & 10.322 & 8.346 & .000 \\
Consumer Sotisfaction & .343 & 4.240 & .000 \\
\hline R Square & .083 & & \\
Adjusted R Square & .079 & & \\
\hline
\end{tabular}

Based on Table 9, it can be seen that the results obtained are consumer satisfaction, the significance of 0.000 is smaller than $0.05(0.000<0.05)$. From result of significance hence can be concluded that consumer satisfaction to behavior of purchasing online. This suggests that the third hypothesis (H3) is supported. The equation of linear regression formula can be explained as follows: $\mathrm{PPO}=10,322+0,343 \mathrm{CS}$. The equation in this regression indicates that there is influence between independent variable to dependent variable.

The meaning of this regression equation is a constant value of 10,322 indicating that consumer satisfaction is constant or fixed, then the average level of online buying behavior is 10,322 . The regression coefficient of consumer satisfaction of 0.343 has the importance of customer satisfaction increased one unit will be followed by the amount of online purchasing behavior of 0.343 . Coefficient of determination (Adjusted R2) of 0.079 this means that $7.9 \%$ of online purchasing process can be influenced by consumer satisfaction variable, while the remaining $92.1 \%$ indicator with other variables outside the model.

\section{Simultaneous Significance Test (F Test)}

Table 10

Test Results F

\begin{tabular}{lccc}
\hline \multicolumn{1}{c}{ Variabel } & Koefisien Regresi & thitus & Sig. \\
\hline Konstanta & 6.627 & 3.602 & .000 \\
Perceived Ease Of Use $(X 1)$ & .262 & 3.438 & .001 \\
Perceived Usefuiness $(X 2)$ & -.015 & .204 & .839 \\
Consumer Sotisfaction $(X 3)$ & .199 & 2.142 & .033 \\
Fitusus $=10.562$ & & & \\
$\mathrm{R}^{2}=.139$ & & & \\
\hline
\end{tabular}

F Test basically indicates whether all independent or independent variables included in the model have a mutual influence on the dependent or dependent variable. Testing uses a significance level of $5 \%$ or 0.05 . The basis of decision making in the regression test is if the value Fcount $>$ Ftable then the hypothesis accepted. Conversely, if Fhount <Ftabel then the hypothesis is rejected. The calculated $F$ value is obtained from the SPSS output on the top row by looking at the $\mathrm{F}$ value while the $\mathrm{F}$ value of the table is seen from the 5\% alpha significance table of 2.06. The results of the analysis can be seen in Table 10 . 
Based on Table 10, the value of Coefficient of Determination (R2) is 0.139 . The meaning of this coefficient is that the relative contribution given by the combination of perceived ease of use (X1), perceived usefulness $(\mathrm{X} 2)$, consumer satisfaction $(\mathrm{X} 3)$ to online purchasing behavior ( $\mathrm{Y}$ ) is $13.9 \%$ while the rest is influenced by other variables. F value count 10.562 with significance level $0.000<0.05$. From the results of significance it can be concluded that the three independent variables simultaneously affect the buying behavior online. This suggests that the fourth hypothesis (H4) is supported. The equation of multiple linear regression equations can be written as follows:

$$
\begin{array}{ll}
Y & =\alpha+\beta 1 . X 1+\beta 2 . X 2+\beta 3 . X 3+\varepsilon \\
P P O & =\alpha+\beta 1 P E O U+\beta 2 P U+\beta 3 C S+\varepsilon \\
P P O & =6.627+0.262 P E O U-0.015 P U+0.199 C S+\varepsilon
\end{array}
$$

The interpretation of the multiple linear regression equation is:

$\mathrm{A}=6.627$ states that if perceived ease of use, perceived usefulness, and consumer satisfaction remain unchanged, the value of consistency of online purchasing behavior is 6.627 .

$\beta 1=0.262$ states that if perceived ease of use increases, then the online purchasing behavior will increase by 0.262 , assuming no additions (constant) perceived usefulness and consumer satisfaction value.

$\beta 2=-0.015$ states that if perceived usefulness increases, then the online purchasing behavior will decrease by -0.015 , assuming no additions (constant) perceived value of ease of use and consumer satisfaction.

$\beta 3=0.199$ states that if consumer satisfaction increases, then the behavior of online purchases will increase by 0.199 , assuming no additions (constant) perceived value of ease of use and perceived usefulness.

\section{Discussion}

\section{The Influence of Perceived Ease of Use Toward Online Purchase Behavior}

The results of statistical tests shows that the variable perceived ease of use affects the behavior of online purchasing. This suggests that the first hypothesis (H1) is supported which means the higher perceived ease of use perceived by the consumer, the higher the consumer behavior in making online purchases. This is in accordance with the results of research Widiyanto and Lestari (2015) which states that perceived ease of use significant effect on attitudes on the purchase online.

\section{The Influence of Perceived Usefulness toward Online Purchase Behavior}

The results of statistical tests shows that the variable perceived usefulness effect on online purchasing behavior. This suggests that the second hypothesis (H2) is supported which means the higher perceived usefulness perceived by consumers, the higher the consumer behavior in making online purchases. This is in accordance with the results of research Moch Suhir et al., (2014) stating that perceived usefulness have a significant effect on the decision of purchasing online.

\section{The Influence of Consumer Satisfaction toward Online Purchase Behavior}

The results of statistical tests shows that consumer satisfaction variables affect the buying behavior online. This suggests that the third hypothesis (H3) is supported which means higher consumer consumer perceived higher consumer behavior in making online purchases. This is in accordance with the results of research Sidharta and Suzanto (2015) which states that consumer satisfaction affects consumer confidence in shaping attitudes and behavior to make online purchases.

\section{The Influence of Perceived Ease of Use, Perceived Usefulness and Consumer Satisfaction towards Online Purchase Behavior}

The statistical test results that perceived ease of use, perceived usefulness and consumer satisfaction variables simultaneously affect the buying behavior of online. This suggests that the fourth hypothesis (H4) is supported which means that the higher perceived ease of use, perceived usefulness and consumer satisfaction perceived by consumers, the higher the consumer behavior in making online purchases.

\section{Conclusion}

Based on the results of research and discussion that has been done, it can be concluded that:

1. Perceived ease of use affects the online buying behavior, the higher perceived ease of use perceived by consumers the higher the consumer behavior in 
making online purchases. Ease of use in online shopping will cause potential customers no trouble in making a purchase.

2. Perceived usefulness affects the online buying behavior, the higher perceived usefulness perceived by consumers the higher the consumer behavior in making online purchases. Perceived usefulness relates to the extent to which one finds benefit in using technology applications.

3. Consumer satisfaction effect on online purchasing behavior, the higher consumer satisfaction perceived consumer then the higher consumer behavior in making online purchases. Consumer satisfaction is concerned with the individual's perception of the performance of the product or service in relation to expectations or expectations.

4. Perceived ease of use, perceived usefulness and consumer satisfaction simultaneously affect the buying behavior of online. The higher perceived ease of use, perceived usefulness and consumer satisfaction perceived by consumers, the higher the consumer behavior in making online purchases.

Researchers found some limitations in this study which can later be improved in subsequent research. The limitations in this study were to study only the general population with the age group of 19-34 years, here the researchers did not study the general population under the age of 19 years or over 34 years. Then the independent variable can still be added with other variables for better future research.

The results of this study indicate that the influence of perceived ease of use on online purchasing behavior. This shows that to improve the online buying behavior, the company should pay attention to the ease of use of the website, so that consumer interaction with the website website is clear and easy to understand.

In addition to being affected by perceived ease of use, online purchasing behavior is also affected by perceived usefulness. Companies should pay attention to aspects of productivity and effectiveness for the website used to make the job easier and useful. Consumer satisfaction has a positive effect on online purchasing behavior. Companies should pay attention to aspects of service and product diversity, so that consumers feel satisfied and make repurchase on the site.
To provide ease of use to web sites, we recommend adding the features and clear menus for easy understanding. The company must also provide information about the product in full so that consumers get enough information in order to make a decision to make a purchase. When the consumer has made a decision to buy, the company must also be alert and serve the seller well and friendly and consistent both in terms of product and delivery of goods.

Suggestions for the future should the sample used in this study more extended again, not only the general public with the age of 19-34 years but also people under the age of 19 years and above 34 years. For future research to add several other variables to examine online purchasing behavior and independent variables can be broken into two, so that the research can find out how much the purchase behavior of both planned purchases and unplanned purchases.

\section{References}

Ajzen, I., \& Fishben, M. F. (1980). Understanding Attitudes and Predicting Social Behavior. New York: Prentice-Hall.

Baudrillard, J. (1998). La Societe de Consommation: Ses Mytes, ses Structures. Paris: Denoel. Diterjemah kan oleh Sage Publication. London: SAGE Publication.

Cox, D. F. (1967). The Sorting Rule Model of The Consumer Product Evaluation Process. Boston: Harvard University.

Davis, F. D. (1989). Perceived Usefulness, Perceived Ease Of Use, and User Aceeptance Of Information Technology. MIS Quarterly, 983-1003.

EMarketer. (2014). Pengguna Internet Indonesia Nomor Enam Dunia. Retrieved from https://kominfo.go.id/ content/detail/4286/pengguna-internet-indonesia-nomor-enamdunia/0/soro-tan_media.

Ghozali, I. (2012). Aplikasi Analisis Multivariate dengan Program SPSS. Semarang: Badan Penerbit Univer sitas Diponegoro.

Hendry. (2012, 08 20). Ukuran Sampel Menurut Para Ahli. Retrieved from https: //teorionlinejurnal.wordpress. com/2012/08/20/menentukan-ukuran-sam pel-menurut-para-ahli/

Kotler, P., \& Keller, K. L. (2012). Marketing Management 14th. New Jersey: Prentice Hall.

Sidharta, I., \& Suzanto, B. (2015, Juni). Pengaruh Kepuasan Transaksi Online Shopping Dan Kepercayaan Konsumen Terhadap Sikap Serta Perilaku Konsumen Pada E Commerce. Retrieved from Jurnal Computech \& Bisnis.

Widiyanto, I., \& Prasilowati2, S. L. (2015). Perilaku pembelian melalui internet. Jurnal manajemen dan kewirausahaan, VOL.17, NO. 2, 109-112. 